\title{
Comparison of Apically Extruded Debris Associated with Different Irrigation Techniques after Removal of Intracanal Medicaments
}

\author{
Shaimaa Nasr El-Din ${ }^{1}$ D, Magdy M. Ali $^{2}$, Reham Hassan ${ }^{3 *}$ (iD \\ ${ }^{1}$ Department of Endodontics, Faculty of Dentistry, Misr University for Science and Technology, October City, Egypt; ${ }^{2}$ Department \\ of Endodontics, Faculty of Dentistry, Beni Suef University, Beni Suef, Egypt; ${ }^{3}$ Department of Endodontics, Faculty of Dentistry, \\ Minia University, Minya, Egypt; ${ }^{3}$ Department of Endodontic, Faculty of Dentistry, The Egyptian Russian University, Badr City, \\ Egypt
}

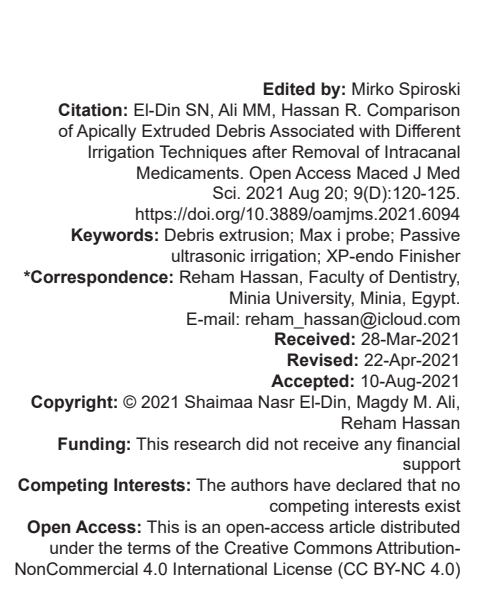

\begin{abstract}
AIM: This study aimed to compare the effect of XP-endo Finisher file (XPF), passive ultrasonic irrigation (PUI) and conventional irrigation technique using side-vented needle (SVN) on the amount of apically extruded debris after the removal of calcium hydroxide $\mathrm{Ca}(\mathrm{OH})_{2}$ and double antibiotic paste (DAP).

MATERIALS AND METHODS: Sixty extracted human mandibular premolars were used. After decornation, all canals were prepared up to the ProTaper Next X4 file (Dentsply Maillefer, Ballaigues, Switzerland). After dryness, teeth were randomly assigned into two groups $(n=30)$ according to the Type of intracanal medication used; $\mathrm{Ca}(\mathrm{OH})_{2}$ and $\mathrm{DAP}$ then incubated at $37^{\circ} \mathrm{C}$ and $100 \%$ humidity. After 1 week, samples in each group were randomly assigned to three subgroups $(n=10)$ according to the method used for medicament removal: XPF, PUI, and SVN. Debris extruded during the removal procedure were collected into pre-weighed Eppendorf tubes then left to dry in an incubator at $37^{\circ} \mathrm{C}$ for 15 days. The amount of extruded debris was assessed with an analytical balance and calculated by subtracting the initial weight from the final weight of the tube. Data were statistically analyzed using Kruskal-Wallis and Mann-Whitney U-test.

RESULTS: There was no statistically significant difference regarding the amount of apically extruded debris after using the three irrigation techniques in removal of both $\mathrm{Ca}(\mathrm{OH})_{2}$ and $\mathrm{DAP}(\mathrm{p}=0.141$, Effect size $=0.160)$ and $(p=0.237$, Effect size $=0.073)$, respectively
\end{abstract}

CONCLUSIONS: Neither XPF nor PUI increase the risk of intracanal medicament extrusion beyond the apex.

\section{Introduction}

The main goal of successful root canal treatment is complete elimination of intracanal bacterial population. For this purpose, chemomechanical preparation is considered the first option to reduce the microorganism inhabitants including various instrumentation techniques and irrigation protocols. Considering the complexity of root canal morphology, none of the contemporary mechanical preparation techniques can result in bacteria-free root canal system [1]. On the contrary, there is accumulated evidence that significant percentage of the root canal wall is left untouched after mechanical instrumentation [2]. Therefore, additional chemical treatment including intracanal medications is required to disinfect the root canal system and to eliminate and/ or decrease the bacteria loads which contribute to the healing of the affected periapical tissue [3], especially in cases where the chemo-mechanical preparation cannot alleviate the symptoms. With the advancement in the field of endodontics, newer antibacterial agents are being tested such as nanoparticles [4]. However, the two mostly used intracanal medicaments (ICMs) are calcium hydroxide $\left(\mathrm{Ca}(\mathrm{OH})_{2}\right)$ and antibiotic pastes.

Infections of the root canal system are polymicrobial in nature, with both aerobic and anaerobic bacterial species [5]. Thus, a single antibiotic may not be effective in the disinfection of root canals. The use of combination of antibiotics has been suggested to address the diverse flora encountered and decrease the possibility of the development of resistant bacterial strains [6]. The most widely used combination is triple antibiotic paste which consists of metronidazole, ciprofloxacin, and minocycline; this formulation was later modified by the removal of minocycline to avoid tooth discoloration forming double antibiotic paste (DAP) [7].

Intracanal medications should be removed prior to the obturation phase in conventional root canal therapy. The previous studies have shown that remnants of medicaments could directly result on discoloration of the teeth, decrease in root dentin micro-hardness, and act as a physical barrier along the sealer/dentin interface, which hinder the penetration of sealers into the dentinal tubules and negatively affects the quality 
of the root filling and subsequently affect the treatment outcomes [8], [9].

Several techniques have been recommended for efficient removal of ICMs, irrigant agitation by passive ultrasonic irrigation (PUI) is the most commonly used method. PUI based on transmission of energy from an ultrasonically oscillating instrument to the irrigant inside the root canal [10].

Another instrument that can be used for agitation is the XP-endo Finisher (XPF: FKG, Dentaire SA, La Chaux-de-Fonds, Switzerland) which is made from a Max-wire alloy. XPF change from martensite phase at room temperature into austenite phase with a curved shape which is able to expand up to $6 \mathrm{~mm}$ in diameter to touch and clean highly complex morphologies and difficult to reach areas at body temperature [11].

Despite strict regulation of the working length (WL) during chemo-mechanical preparation, dentin chips, pulp tissue, microorganisms, and irrigants are eventually forced into the periapical tissues from the root canal. This is of concern, as the extrusion of these elements may trigger undesired consequences in the form of acute inflammatory response, post-instrumentation pain; inter appointment flare-up [12], and prolonged periapical healing time [13]. Therefore, in the procedure of root canal treatment, it is of prime importance to prevent debris extrusion. It could be suggested that various techniques used to remove ICMs could also result in debris extrusion.

In subcutaneous tissues, clinical concentrations of $\mathrm{Ca}(\mathrm{OH})_{2}$, DAP can lead to a moderate inflammatory reaction and are cytotoxic to human dental pulp stem cells [7]. The complete removal of these drugs from the root canal with the lowest amount of debris extrusion during the removal is therefore an important step for the success of the treatment.

The ability of different irrigating solutions and activation techniques to remove ICMs have been previously studied [10], [11], [14], however up to the best of our knowledge; no study to date evaluated the weight of apically extruded debris produced by the removal procedure. Thus, the aim of this study was to compare the amount of apically extruded debris resulting from the removal of both $\mathrm{Ca}(\mathrm{oH})_{2}$ and DAP in the mature straight root canal with XPF, PUI, and side-vented needle (SVN). The null hypothesis was that there is no difference between different techniques used in the weight of apically extruded debris.

\section{Materials and Methods}

\section{Sample size calculation}

Based on the results of Gawdat and El Asfouri [15], the mean values for conventional syringe, PUI, and XPF groups were (0.006), (0.0009), and (0.0008), respectively. Using a standard deviation of 0.0002 within each group; the effect size (f) was found to be (0.62). Using alpha ( $\alpha$ ) level of $(5 \%)$ and Beta $(\beta)$ level of $(20 \%)$, that is, power $=(80 \%)$; the minimum estimated sample size was (10) specimens per instrument in each group, giving a total of (60) specimens in both groups. Sample size calculation was performed using IBM $^{\circledR}$ SPSS $^{\circledR}$ SamplePower $^{\circledR}$ Release 3.0.1.

\section{Sample selection}

Ethical approval was obtained from the ethical committee, Faculty of Dentistry, Minia University, Egypt (Registration no 59/311). Sixty, straight, single-rooted human mandibular premolars, freshly extracted for orthodontic, or periodontal reasons were collected from the Department of Oral and Maxillofacial surgery, Faculty of dentistry, Minia University, Egypt. Teeth were disinfected by immersion in $5.2 \%$ sodium hypochlorite $(\mathrm{NaOCl}$; Clorox, HC Egyptian Company, Cairo, Egypt) for $1 \mathrm{~h}$. Soft tissues and calculus were removed mechanically from the root surfaces with a periodontal scaler. Teeth were examined under surgical operating microscope (Global Surgical Corp; USA) for caries, fractures, cracks, or resorptions. Buccolingual and mesiodistal radiographs were taken to evaluate the root canal anatomy and ensure the presence of single root canal. Teeth with curved canals, cracks, resorptive defects, or previous endodontic treatment were excluded from the study.

\section{Sample preparation}

Decornation was done using a tapered diamond stone mounted on low-speed hand piece under water coolant to obtain a standardized root length of $15 \mathrm{~mm}$. Root canal patency was checked and the WL was determined using K-files \#15 (Dentsply Sirona, York, PA, USA) placed until it became visible at the apical foramen and subtracting $1 \mathrm{~mm}$ from that length of the file. Root canal preparation was performed using ProTaper Next rotary files (Dentsply Sirona, Ballaigues, Switzerland) in a crown-down fashion to the WL with an apical enlargement up to a file size $\times 4(0.40 / 0.06)$ using an endodontic motor (X-Smart, Dentsply-Maillefer, Ballaigues, Switzerland) at $300 \mathrm{rpm}$ and $2 \mathrm{Ncm}$ torque according to the manufacturer's instructions. Root canals were irrigated with $2 \mathrm{~mL} 5.25 \% \mathrm{NaOCl}$ using a 30 gauge (G) SVN (Max-i-Probe, Dentsply, Rinn, IL, USA) at every instrument change. Final irrigation was completed using $5 \mathrm{~mL} \mathrm{17 \%} \mathrm{EDTA} \mathrm{for} 1 \mathrm{~min}$ and $5 \mathrm{~mL}$ $5.25 \% \mathrm{NaOCl}$ for $1 \mathrm{~min}$, followed by the final rinse with $5 \mathrm{~mL}$ distilled water. Finally, canals were dried using sterile paper points (Dentsply Maillefer, Ballaigues, Switzerland). 


\section{Sample grouping}

Samples were randomly divided into two equal experimental groups using a random group allocation online software (https://www.ramdomizer. org) according to the type of i ICM used with either $\mathrm{Ca}(\mathrm{OH})_{2}$ or DAP $(\mathrm{n}=30)$.

\section{Preparation of the ICMs}

In Group $\mathrm{A} ; \mathrm{Ca}(\mathrm{OH})_{2}$ paste (UltraCal $^{\circledR}$; Ultradent, South Jordan, UT, USA) was placed using a Navitip $29 \mathrm{G}$ tip (Ultradent, South Jordan, UT, USA) starting $1 \mathrm{~mm}$ shorter than WL then moved coronally until the paste was visible at the canal orifice.

In Group B; DAP was prepared by grinding an equal number of tablets of $500 \mathrm{mg}$ metronidazole (Flagyl; Aventis, Cairo, Egypt) and 500 mg ciprofloxacin (Ciprofar; pharco, Alexandria, Egypt). The powder (1:1) was then mixed with distilled water. The paste was applied to the canal spaces with $3 \mathrm{~cm}$ plastic syringe.

In both groups, excess material extruded from the apex was wiped off with moist cotton, cotton pellets were placed over the canal orifices, and a temporary sealing material (Cavit G; 3M ESPE, Seefeld, Germany) was used to seal the access cavities. Then, all samples were stored at $37^{\circ} \mathrm{C}$ in $100 \%$ relative humidity for 1 week.

\section{Debris extrusion collection}

The experimental model described by Myers and Montgomery in 1991 [16] was used in this study. The stoppers of Eppendorf tubes were removed, and tubes were numbered and weighed using an analytical balance (Adam Equipment Co. Ltd, MK10 OBD. UK) with an accuracy of $10^{-4} \mathrm{~g}$. Three consecutive weights were obtained for each tube, and the mean value was considered to be its initial weight (W1). A hole was created with a heated instrument in the center of the rubber stopper of each tube, and then each tooth was inserted under pressure into the rubber stopper and fixed at the cemento-enamel junction using cyanoacrylate glue. A 27G needle was placed alongside the cover as a drainage cannula to equalize the internal and external air pressure. Next, each unit including the stopper, tooth and needle, was fixed to its Eppendorf tube. The tubes were fitted into vials to hold the device during preparation. The operator was blinded from seeing the root apex during the removal procedure by covering the vial with aluminum foil. In each group, samples were randomly divided into three equal subgroups $(n=10)$ as follows;

\section{Subgroup l; (XPF)}

The specimens were rinsed with $10 \mathrm{~mL}$ distilled water using a 30G SVN (Maxi-i-probe, Dentsply, Rinn,
$\mathrm{IL}$, USA) placed $1 \mathrm{~mm}$ from the $\mathrm{WL}$ with a flow rate of approximately $5 \mathrm{~mL} / \mathrm{min}$. XPF file (size 25, 0.00 taper) (FKG, LaChaux-de-faund, Switzerland) was used with an endodontic motor (X-Smart, Dentsply-Maillefer, Ballaigues, Switzerland) at $800 \mathrm{rpm}$ and $1 \mathrm{Ncm}$ torque according to the manufacturer's instructions [17]. The file was inserted $1 \mathrm{~mm}$ shorter than the WL which was adjusted using the plastic tube to fix the rubber stopper. The canal was filled with irrigant and the finisher was operated for $60 \mathrm{~s}$ using slow and gentle $7-8 \mathrm{~mm}$ lengthwise in-and-out movements. Each file was used for one canal in order to prevent interfering with the debris extrusion results.

\section{Subgroup II; (PUI)}

Using IrriSafe ultrasonic tip (size 25, 0.00 taper) (Acteon, France) mounted on an ultrasonic system (Newtron P5; Satelec, Acteon group, France) in an endo power setting at the $5^{\text {th }}$ power. The root canal of each specimen was rinsed with $10 \mathrm{~mL}$ distilled water using 30G SVN (Max-i-Probe, Dentsply, Rinn, IL, USA) placed $1 \mathrm{~mm}$ from the $\mathrm{WL}$ with a flow rate of approximately $5 \mathrm{~mL} / \mathrm{min}$. Then, the IrriSafe tip was inserted into the canal $1 \mathrm{~mm}$ short of the $\mathrm{WL}$, and the irrigant was ultrasonically activated for $20 \mathrm{~s}$. This sequence was repeated 2 more times; the tip was kept as centered as possible to minimize contact with the canal walls, as any contact with the canal wall could dampen the oscillatory motion of the tip by Jiang et al. [18]. Each tip was used for one canal to prevent interfering with the debris extrusion results.

\section{Subgroup III; (SVN)}

Root canals were rinsed with $10 \mathrm{~mL}$ distilled water using a $5 \mathrm{~mL}$ disposable plastic syringe and $30 G$ SVN (Max-i-Probe, Dentsply, Rinn, IL, USA). The needle was inserted passively up to $1 \mathrm{~mm}$ short of the WL with a flow rate of approximately $5 \mathrm{~mL} / \mathrm{min}$. During irrigation, the needle was constantly moved up and down within the apical third.

The irrigants temperature, flow rate, volume, and activation time were standardized for all groups. Rubber stoppers were placed on the XPF, IrriSafe ultrasonic tip, and the needle at the required length to ensure length control. In all groups, saline solution was warmed to $37^{\circ} \mathrm{C}$ before use to allow the XPF to work optimally at the austenite phase.

\section{Assessment of debris extrusion}

On completion of the intracanal removal procedure, the stoppers, needles, and teeth were gently removed from their tubes and vials, then the debris adhered to the root surface were collected by washing off the apex with $1 \mathrm{~mL}$ of distilled water into the tube. Eppendorf tubes were stored in an incubator at $37^{\circ} \mathrm{C}$ 
for 15 days to evaporate the moisture before weighing the dried debris. Weighing procedure was carried out again using the same balance and three consecutive weights were obtained for each tube, followed by calculating the mean. These measurements considered to be the weight of the tube plus the debris (W2). The dried weight of the extruded debris was calculated by subtracting the weight of the empty tube from that of the tube containing debris (W2-W1).

All root canals were prepared, by the same experienced operator (S.N) to reduce inter-operator variability, while measurements were done by an examiner who was blinded to the study groups (R.H).

\section{Statistical analysis}

Numerical data were explored for normality by checking the distribution of data and using tests of normality (Kolmogorov-Smirnov and Shapiro-Wilk tests). All data showed non-normal (non-parametric) distribution. Data were presented as median, range, mean and standard deviation (SD) values. MannWhitney U-test was used to compare between the two materials with each technique. Kruskal-Wallis test was used to compare between the three irrigation techniques. Dunn's test was used for pair-wise comparisons when Kruskal-Wallis test is significant. The significance level was set at $p \leq 0.05$. Statistical analysis was performed with IBM SPSS Statistics for Windows, Version 23.0. Armonk, NY: IBM Corp.

\section{Results}

Figure 1 shows the median and range values of the amount of apically extruded debris of the

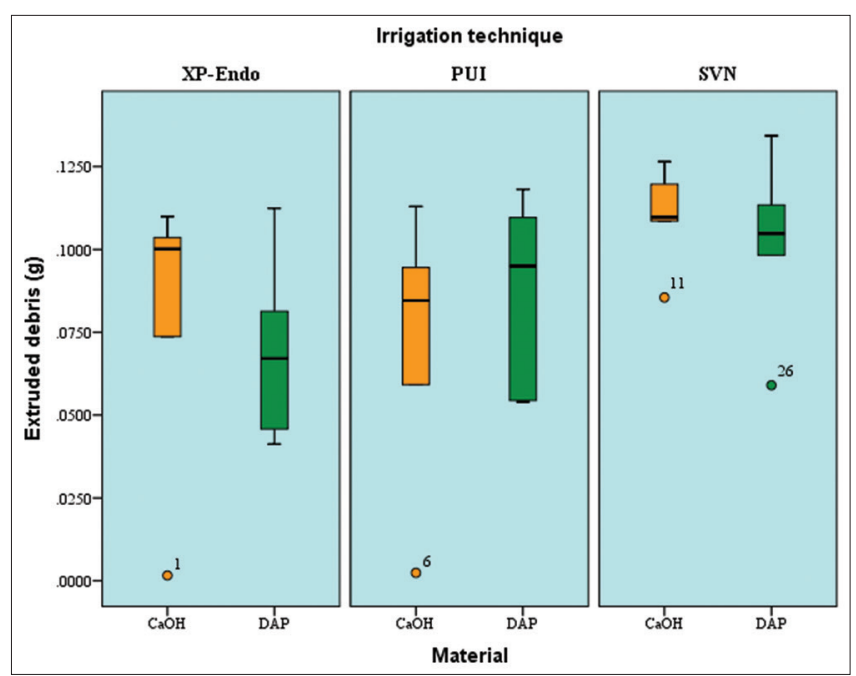

Figure 1: Box plot representing median and range values for the amounts of apically extruded debris in medicaments (circles represent outliers) two materials; there was no statistically significant difference regarding to the amount of apically extruded debris between the two medicaments using XPF, PUI, and SVN ( $p=0.602$, Effect size $=0.335)$. As regard $\mathrm{Ca}(\mathrm{OH})_{2}$ and DAP group; in each group there was no statistically significant difference in the amounts of apically extruded debris after using the three irrigation techniques $(P$-value $=0.141$, Effect size $=0.160)$ and $(p=0.237$, Effect size $=0.073)$, respectively (Table 1$)$.

Table 1: Descriptive statistics and results of Kruskal-Wallis test for comparison between apical extruded debris after using the three irrigation techniques

\begin{tabular}{|c|c|c|c|c|}
\hline \multirow[t]{2}{*}{ Irrigation technique } & \multicolumn{2}{|l|}{$\mathrm{Ca}(\mathrm{OH})_{2}$} & \multicolumn{2}{|l|}{ DAP } \\
\hline & Median (range) & Mean (SD) & Median (range) & Mean (SD) \\
\hline$\overline{\mathrm{XPF}}$ & 0.1002 & 0.0778 & 0.0671 & 0.0696 \\
\hline & (0.0016-0.1099) & $(0.0448)$ & $(0.0413-0.1124)$ & $(0.0289)$ \\
\hline PUI & 0.0846 & 0.0707 & 0.095 & 0.0862 \\
\hline SVN & $\begin{array}{l}0.1097 \\
(0.0855-0.1265)\end{array}$ & $\begin{array}{l}(0.11 \\
(0.0156)\end{array}$ & $\begin{array}{l}0.1048 \\
(0.059-0.1343)\end{array}$ & $\begin{array}{l}0.102 \\
(0.0276)\end{array}$ \\
\hline $\mathrm{p}$ & 0.141 & & 0.237 & \\
\hline Effect size (Eta Squared) & 0.160 & & 0.073 & \\
\hline
\end{tabular}

\section{Discussion}

Every effort should be made to reduce the apical extrusion of debris, bacteria, and irrigants beyond the apex as it could result in undesirable consequences such as induction of inflammation and inter-appointment flare-ups [12], [19] in addition to postoperative pain, and delayed periapical healing where the incidence of these complications is reported to range between $1.4 \%$ and $16 \%[20]$.

Apical extrusion of debris and irrigants was found to be influenced by many factors such as; root canal anatomy, instrument size, type, canal preparation technique, apical enlargement, apical stop, irrigation solutions, techniques, and devices, in addition to canal curvature and the presence of more than one canal [21], [22], [23]. Therefore, only single rooted teeth with straight canal were used in this study in a trial to eliminate variables which might interfere with the results. In addition, mature teeth were only included; ruling out teeth with incomplete root growth where dentin mineralization is less intense than mature teeth, making them more susceptible to wear, leading to increased extrusion [12]. The length of root canals was standardized by sectioning the crowns in a trial to homogenize the amount of ICM placed in all teeth.

Shuping et al. [24] showed that placement of $\mathrm{Ca}(\mathrm{OH})_{2}$ for at least 1 week rendered $92.5 \%$ of canals bacteria free. Removal procedure in the current study was performed after 1 week to simulate the clinical situation. Changes in surface properties and deterioration of the mechanical properties of root canal dentin were previously demonstrated when endodontic medicaments were used for long-term periods [25]. 
Distilled water was used as an irrigant in the present study to highlight the potential effect of the activation techniques merely and to avoid the possible crystallization of $\mathrm{NaOCl}$, which could change the weight of the apically extruded debris and compromise the reliability of the results [26].

The extrusion of irrigants is affected by the depth of needle tip placement. The further the needle is positioned coronally, the less apical pressure is developed, but the irrigant exchange becomes less efficient [27]. For standardization purpose, the needle was placed $1 \mathrm{~mm}$ short of the WL in all groups, needle binding into the root canal walls was avoided to prevent pushing material into the periapex.

One of the limitations of the present study was the inability to simulate the intracanal temperature, while the XPF instruments can only function properly at body temperature (austenitic phase) [17]; however, placing the teeth in hot water bath as mentioned in other studies such as Hamdan et al. [28] would have an impact on the solubility of the ICMs plus disturbing the debris extrusion results. To overcome this limitation, distilled water used as irrigant was preheated to $37^{\circ} \mathrm{C}$ to mimic body temperature.

Result showed that, all irrigation techniques used were associated with some level of apically extruded debris without significant differences between them (Figure 1), $(p=0.141$, Effect size $=0.160)$ and $(p=0.237$, Effect size $=0.073)$ in both $\mathrm{Ca}(\mathrm{OH})_{2}$ and DAP, respectively, thus the null hypothesis was accepted. This was in line with a previous study by Dos Reis et al. [29] who showed no significant difference in the irrigant extrusion between no agitation group, ultrasonic agitation with Irrisonic, ultrasonic agitation with Irrisonic Power, mechanical agitation with Easy Clean and the XPF. On the other side, a study conducted by Gummadi et al. [22] concluded that during instrumentation; conventional irrigation extruded significantly more debris apically compared to PUI. This could be explained as open-ended needles generate positive pressures in excess of central venous pressure, as stated by Khan et al. [30]. Also Boutsioukis et al. concluded that, during open-ended needle irrigation there is an increased pressure at the apical foramen indicating increased risk of extrusion toward the periapical tissue [27].

SVN showed the highest amount of apically extruded debris relative to XPF and PUI for both ICMs. The results are in line with a study by Tambe et al. [31] and Dos Reis et al. [29]. Even with closed-end needles extrusion may occur, as the root canal cross-section is not perfectly circular thus, irrigant access to the apical area might not be completely blocked by the needle tip Psimma et al. [32].

Both XPF and PUI caused less debris extrusion than the SVN, the lack of conicity of both instrument and its use in back and forth movements in the canal allow the irrigant to be pushed in coronal direction, which may have minimized its pattern of apical extrusion Keskin et al. [33]. Moreover, instruments with a lower taper probably favor lower volumes of apical extrusion as they provide a larger area of debris escapement space in the coronal direction which is the case with XPF and PUI [29].

\section{Conclusions}

XPF or PUI did not increase the risk of ICM extrusion beyond the apex. Further clinical trials on the post-operative pain incidence after the removal of ICMs using different activation techniques are required.

\section{References}

1. Hülsmann $M$, Peters $O A$, Dummer $P M$. Mechanical preparation of root canals: Shaping goals, techniques and means. Endod Top. 2005;10(1):30-76. https://doi. org/10.1111/j.1601-1546.2005.00152.x

2. Peters OA, Sch€onenberger K, Laib A. Effects of four Ni-T preparation techniques onroot canal geometry assessed by micro computed tomography. Int Endod J. 2001;34(3):221-30. https://doi.org/10.1046/j.1365-2591.2001.00373.x

PMid:12193268

3. Kawashima N, Wadachi R, Suda H, Yeng T, Parashos P. Root canal medicaments. Int Dent J. 2009;59(1):5-11.

PMid:19323305

4. Ionescu A, Harris D, Selvaganapathy PR, Kishen A. Electrokinetic transport and distribution of antibacterial nanoparticles for endodontic disinfection. Int Endod J. 2020;53(8):1120-30. https://doi.org/10.1111/iej.13321

5. Shin JM, Luo T, Lee KH, Guerreiro D, Botero TM, McDonald NJ et al. Deciphering endodontic microbial communities by nextgeneration sequencing. J Endod. 2018;44(7):1080-7. https:// doi.org/10.1016/j.joen.2018.04.003

PMid:29861065

6. Taneja S, Kumari M. Use of triple antibiotic paste in the treatment of large periradicular lesions. J Investig Clin Dent. 2012;3(1):72-6. https://doi.org/10.1111/j.2041-1626.2011.00082.x PMid:22298525

7. Sabrah AH, Yassen GH, Liu WC, Goebel WS, Gregory RL, Platt JA. The effect of diluted triple and double antibiotic pastes on dental pulp stem cells and established Enterococcus faecalis biofilm .Clin Oral Investig. 2015;19(8):2059-66. https://doi. org/10.1007/s00784-015-1423-6

PMid:25689981

8. Yucel AC, Gurel M, Guler E, Karabucak B. Comparison of final irrigation techniques in removal of calcium hydroxide. Aust Endod J. 2013;39(3):116-21. https://doi. org/10.1111/j.1747-4477.2011.00326.x

PMid:24279657

9. Hosoya N, Kurayama H, lino F, Arai T. Effects of calcium hydroxide on physical and sealing properties of canal sealers. Int Endod J. 2004;37(3):178-84. https://doi. org/10.1111/j.0143-2885.2004.00781.x 


\section{PMid:15009407}

10. Arslan H, Akcay M, Capar ID, Saygili G, Gok T, Ertas H An in vitro comparison of irrigation using photon-initiated photoacoustic streaming, ultrasonic, sonic and needle techniques in removing calcium hydroxide. Int Endod $\mathrm{J}$. 2015;48(3):246-51. https://doi.org/10.1111/iej.12306 PMid:24786363

11. Wigler R, Dvir R, Weisman A, Matalon S, Kfir A. Efficacy of $\mathrm{XP}$-endo finisher file in the removal of calcium hydroxide paste from artificial standardized groove in the apical third of oval root canals. Int Endod J. 2010;43(9):763-8. https://doi.org/10.1111/ iej.12668

12. Tanalp J, Gungor T. Apical extrusion of debris: A literature review of an inherent occurrence during root canal treatment. Int Endod J. 2014;47(3):211-21. https://doi.org/10.1111/iej.12137 PMid:23711187

13. Hülsmann M, Rödig T, Nordmeyer S. Complications during root canal irrigation. Endod Top. 2009;16:27-63. https://doi. org/10.1111/j.1601-1546.2009.00237.x

14. Al-Garni S, Al-Sharani S, Al-Nazhan S, Al-Maflehi N. Evaluation of calcium hydroxide removal using EndoActivator system: An in vitro study. Saudi Endod J. 2014;4(1):13-7. https://doi. org/10.4103/1658-5984.127981

15. Gawdat S, El Asfouri H. Comparison of the effect of XP-endo Finisher file, passive ultrasonic irrigation and conventional syringe irrigation on the apical extrusion of debris. Egypt Dent $\mathrm{J}$. 2016;62(10):5107-14. https://doi.org/10.4274/meandros.24008

16. Myers GL, Montgomery S. Comparison of weights of debris extruded apically by conventional filing and canal master techniques. J Endod. 1991;17(6):275-7. https://doi.org/10.1016/ s0099-2399(06)81866-2

PMid:1940753

17. FKG XP-Endo Finisher; 2016. Available from: http://www.fkg.ch/ sites/default/files/201607_fkg_xps_brochure_en_web.pdf. [Last accessed on 2020 Oct 19].

18. Jiang LM, Verhaagen B, Versluis M, Langedijk J, Wesselink $P$, van der Sluis LW. The influence of the ultrasonic intensity on the cleaning efficacy of passive ultrasonic irrigation. J Endod. 2011;37(5):688-92. https://doi.org/10.1016/j.joen.2011.02.004 PMid:21496672

19. Arora C, Bahri R, Mittal N. Comparative evaluation of debris extruded apically by using, Protaper retreatment file, K3 file and $\mathrm{H}$-file with solvent in endodontic retreatment. Saudi Endod J. 2012;2(3):136-41. https://doi.org/10.4103/1658-5984.112706

20. Siqueira JF, Rocas IN, Favieri A, Machado AG, Gahyva SM, Oliveira JC, et al. Incidence of postoperative pain after intraca-nal procedures based on an antimicrobial strategy. J Endod. 2002;28(6):457-60. https://doi. org/10.1097/00004770-200206000-00010

PMid:12067129

21. Caviedes-Bucheli J, Castellanos F, Vasquez N, Ulate E, Munoz HR. The influence of two reciprocating single-file and two rotary-file systems on the apical extrusion of debris and its biological relationship with symptomatic apical periodontitis. A systematic review and meta-analysis. Int Endod J. 2016;49(3):255-70. https://doi.org/10.1111/iej.12452 PMid:25816688

22. Gummadi A, Panchajanya S, Ashwathnarayana S, Santhosh L, Jaykumar T, Shetty A. Apical extrusion of debris following the use of single-file rotary/reciprocating systems, combined with syringe or ultrasonically-facilitated canal irrigation. J Conserv Dent. 2019;22(4):351-5. https://doi.org/10.4103/jcd.jcd_14_19

\section{PMid:31802818}

23. Elmsallati EA, Wadachi R, Suda H. Extrusion of debris after use of rotary nickel-titanium files with different pitch: A pilot study. Aust Endod J. 2009;35(2):65-9. https://doi. org/10.1111/j.1747-4477.2008.00128.x PMid: 19703077

24. Shuping GB, Orstavik D, Sigurdsson A, Trope M. Reduction of intracanal bacteria using nickel-titanium rotary instrumentation and various medications. J Endod. 2000;26(12):751-5. https:// doi.org/10.1097/00004770-200012000-00022 PMid: 11471648

25. Marending M, Stark WJ, Brunner TJ, Fischer J, Zehnder M. Comparative assessment of time-related bioactive glass and calcium hydroxide effects on mechanical properties of human root dentin. Dent Traumatol. 2009;25(1):126-9. https://doi. org/10.1111/j.1600-9657.2008.00735.x

PMid:19208025

26. Topçuoğlu HS, Aktı A, Tuncay Ö, Dinçer AN, Düzgün $S$, Topçuoğlu G. Evaluation of debris extruded apically during the removal of root canal filling material using ProTaper, D-RaCe, and R-Endo rotary nickel-titanium retreatment instruments and hand files. J Endod. 2014;40(12):2066-9. https://doi. org/10.1016/j.joen.2014.09.004 PMid:25443282

27. Boutsioukis $C$, Lambrianidis $T$, Verhaagen $B$, Versluis $M$ Kastrinakis E, Wesselink PR, et al. The effect of needle-insertion depth on the irrigant flow in the root canal: evaluation using an unsteady computational fluid dynamics model. J Endod. 2010;36(10):1664-8. https://doi.org/10.1016/j.joen.2010.06.023 PMid:20850673

28. Hamdan R, Michetti J, Pinchon D, Diemer F, Georgelin-Gurgel M. The XP-Endo Finisher for the removal of calcium hydroxide paste from root canals and from the apical third. J Clin Exp Dent. 2017;9(7):e855-60. https://doi.org/10.4317/jced.53962 PMid:28828150

29. Dos Reis S, Cruz VM, Duarte MA, da Silveira Bueno CE, Vivan RR, Pelegrine RA, et al. Volumetric analysis of irrigant extrusion in immature teeth after different final agitation techniques. J Endod. 2020;46(5):682-7. https://doi. org/10.1016/j.joen.2020.01.014 PMid:32139265

30. Khan S, Niu LN, Eid AA, Looney SW, Didato A, Roberts S, et al Periapical pressures developed by nonbinding irrigation needles at various irrigation delivery rates. J Endod. 2013;39(4):529-33. https://doi.org/10.1016/j.joen.2013.01.001 PMid:23522551

31. Tambe VH, Nagmode PS, Vishwas JR, P SK, Angadi P, Ali FM. Evaluation of the amount of debris extruded apically by using conv-entional syringe, endovac and ultrasonic irrigation technique: An in vitro study. J Int Oral Health. 2013;5(3):63-6. PMid:24155604

32. Psimma Z, Boutsioukis C, Kastrinakis E, Vasiliadis L. Effect of needle insertion depth and root canal curvature on irrigant extrusion ex vivo. J Endod. 2013;39(4):521-4. https://doi. org/10.1016/j.joen.2012.12.018 PMid:23522549

33. Keskin C, Güler DH, Sarıyılmaz E. Effect of intracanal time of triple antibiotic paste on its removal from simulated immature roots using passive ultrasonic irrigation and XP-endo finisher. $\mathrm{J}$ Dent Res Dent Clin Dent Prospects. 2018;12(4):288-93. https:// doi.org/10.15171/joddd.2018.045

PMid:30774796 